\title{
Cyanobactins_-ribosomal cyclic peptides produced by cyanobacteria
}

\author{
Kaarina Sivonen • Niina Leikoski • David P. Fewer • \\ Jouni Jokela
}

Received: 2 September 2009 /Revised: 29 January 2010 / Accepted: 29 January 2010 /Published online: 27 February 2010

(C) The Author(s) 2010. This article is published with open access at Springerlink.com

\begin{abstract}
Cyanobactins are small cyclic peptides that are produced by a diverse selection of cyanobacteria living in symbioses as well as terrestrial, marine, or freshwater environments. They include compounds with antimalarial, antitumor, and multidrug reversing activities and potential as pharmaceutical leads. Cyanobactins are produced through the proteolytic cleavage and cyclization of precursor peptides coupled with further posttranslational modifications such as heterocyclization, oxidation, or prenylation of amino acids. Cyanobactin gene clusters encode two proteases which cleave and cyclisize the precursor peptide as well as proteins participating in posttranslational modifications. The bioinformatic mining of cyanobacterial genomes has led to the discovery of novel cyanobactins. Heterologous expression of these gene clusters provided insights into the role of the genes participating in the biosynthesis of cyanobactins and facilitated the rational design of novel peptides. Enzymes participating in the biosynthesis of cyanobactins may prove useful as catalysts for producing novel cyclic peptides in the future. The recent discovery of the cyanobactin biosynthetic pathway in cyanobacteria extends our knowledge of their potential as producers of interesting metabolites.
\end{abstract}

Keywords Cyanobacteria $\cdot$ Cyanobactins $\cdot$ Peptides . Bioactive compounds

K. Sivonen $(\bowtie) \cdot$ N. Leikoski $\cdot$ D. P. Fewer $\cdot$ J. Jokela

Department of Food and Environmental Sciences,

Division of Microbiology,

Viikki Biocenter, University of Helsinki,

Helsinki P.O. Box 56, Viikinkaari 9,

FIN-00014, Finland

e-mail: kaarina.sivonen@helsinki.fi

\section{Cyanobactins}

Cyanobacteria are one of the most promising microbial groups in the search for novel bioactive compounds. Low molecular weight peptides containing a range of proteinogenic and nonproteinogenic amino acids are a major class of bioactive compounds produced by cyanobacteria (Burja et al. 2001). A plethora of small cyclic or linear peptides with a surprisingly high level of structural variation have been reported from cyanobacteria (Welker and von Döhren 2006; Sivonen and Börner 2008). These peptides are produced by both nonribosomal and ribosomal biosynthetic pathways in cyanobacteria. The first nonribosomal pathways for cyanobacterial peptides were described in 2000 (Tillett et al. 2000; Rouhiainen et al. 2000) whereas the first ribosomal pathway was shown in 2005 for the cyanobactin patellamide (Schmidt et al. 2005).

Cyanobactin was proposed as a collective name for cyclic peptides which contain heterocyclized amino acids or isoprenoid amino acid derivatives (Donia et al. 2008a; Schmidt and Donia 2009). Cyanobactins were initially defined to contain oxazolines, thiazolines, or their oxidized derivatives oxazoles and thiazoles (Fig. 1). This definition was recently broadened to include cyclic peptides which consist solely of proteinogenic amino acids (Leikoski et al. 2010). Isoprenoid amino acid derivatives are rare but found for example in trunkamide, patellin, and anacyclamides (Tables 1 and 3, Fig. 1).

\section{Occurrence and chemical diversity of cyanobactins}

More than a hundred cyanobactins have been identified from symbiotic associations formed between cyanobacteria and ascidians (Table 1) or from free-living cyanobacteria 
Fig. 1 The chemical structures of a selection of cyanobactins. Trunkamide was isolated from L. patella, tenuecyclamide from $N$. spongiaeforme, anacyclamide from Anabaena, trichamide from T. erythraeum, and ulithiacyclamide and patellamide from Prochloron (originally from $L$. patella). The corresponding biosynthetic gene clusters are shown in Fig. 2
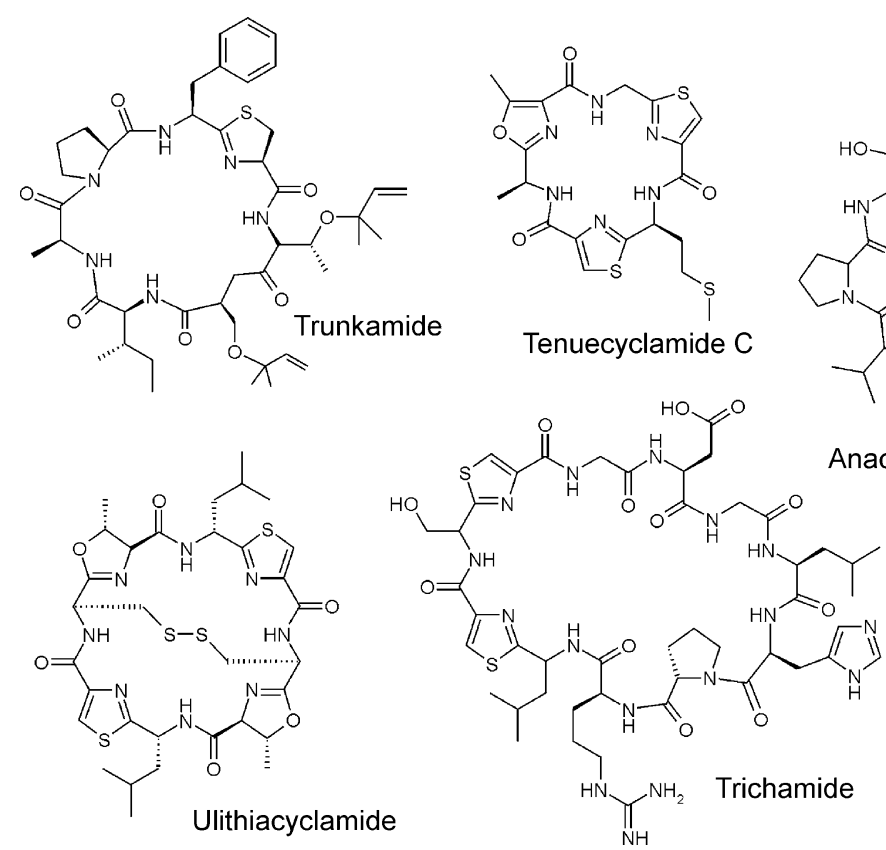

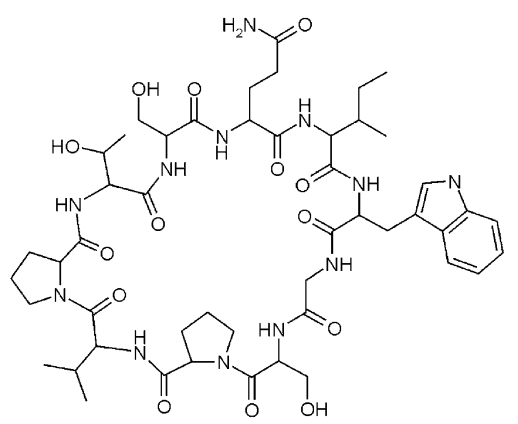

Anacyclamide A10

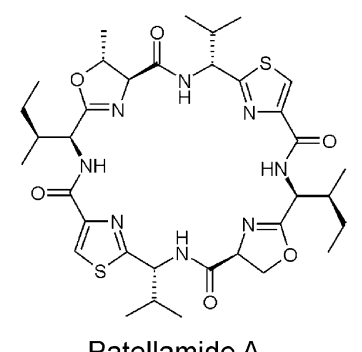

(Tables 2 and 3, Fig. 1). This makes cyanobactins one of the largest classes of cyanobacterial peptides (Donia et al. 2006; Schmidt and Donia 2009). Cyanobactins identified from filter-feeding organisms, such as ascidians and sponges, usually contain from six to ten amino acids and varying numbers and combinations of oxazoles, oxazolines, thiazoles, and thiazolines. A few cyanobactins, such as comoramides, contain prenylated amino acids, and ulithiacyclamides have disulfide bridges between two cysteine amino acids (Table 1).

It is unclear if the cyanobactins are produced by the filterfeeding organisms themselves, heterotrophic bacteria, or cyanobacteria associated with these organisms (Table 1). Some cyanobactins have now been verified to be produced by cyanobacteria (Schmidt et al. 2005; Donia et al. 2006). The biosynthetic origin of most of the analogous cyclic peptides reported from cyanobacteria (Tables 2 and 3) is currently unknown. To date, only ribosomal biosynthetic pathways have been described to produce these cyclic peptides (Schmidt et al. 2005; Donia et al. 2006, 2008a; Sudek et al. 2006; Ziemert et al. 2008b; Leikoski et al. 2010). However, a nonribosomal peptide synthetase pathway could be an alternative route for the biosynthesis of these compounds.

Cyanobacterial strains produce ribosomal cyanobactins which contain heterocyclized amino acids (Table 2) and also cyclic peptides which consist solely of unmodified proteinogenic amino acids, occasionally with prenyl attachments (Table 3). Cyanobactins which are found in by cyanobacteria and contain heterocyclized amino acids range in size from six to eleven amino acids (Table 2). Oxazoles and thiazoles are common while oxazolines or thiazolines occur with a lower frequency (Table 2). The cyanobactins which lack heterocyclized amino acids vary in length from seven to 20 amino acids (Table 2). Interestingly, a feature uniting cyanobactins without heterocyclized amino acids in addition to the occasional prenyl attachment is the conserved presence of a proline residue (Table 3).

The biosynthetic genes for cyanobactin production have been described in distantly related cyanobacteria Prochloron, Trichodesmium, Microcystis, Nostoc, Lyngbya, and Anabaena (Schmidt et al. 2005; Donia et al. 2006, 2008a; Sudek et al. 2006; Ziemert et al. 2008b; Leikoski et al. 2010; Fig. 2). In addition, one of the protease genes responsible for cleavage of the cyanobactin precursor peptide was shown to be common among planktonic freshwater cyanobacteria and present in 48 out of 132 strains studied (Leikoski et al. 2009). These planktonic cyanobacteria included fresh and brackish water strains from filamentous heterocystous (Anabaena, Aphanizomenon, Nodularia), filamentous (Planktothrix), as well as colony-forming (Microcystis and Snowella) cyanobacteria. The biosynthetic pathway appears to be relatively common in these strains (Leikoski et al. 2009), but detailed analysis of the gene clusters should be carried out and the structure of the compounds remains to be identified.

\section{Biosynthesis of cyanobactins}

Cyanobactins are produced through the proteolytic cleavage and head-to-tail (N-C) cyclization of precursor peptides coupled with modification of specific amino acids as in many other natural products (Oman and van der Donk 2010). The cyclic structure is formed via an amide linkage of the $\alpha$-carbonyl of $\mathrm{C}$-terminal amino acid and $\alpha$-amino 


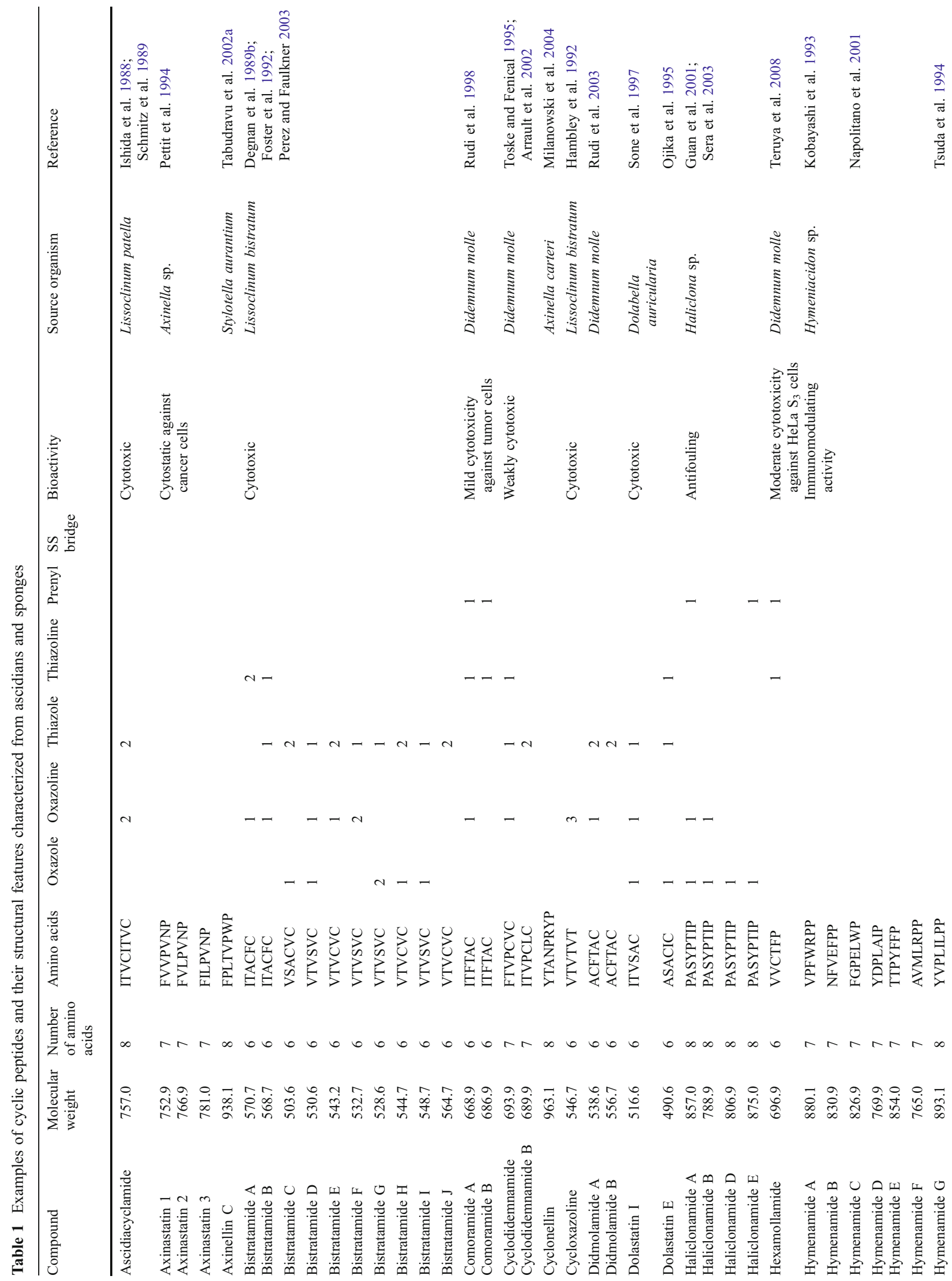




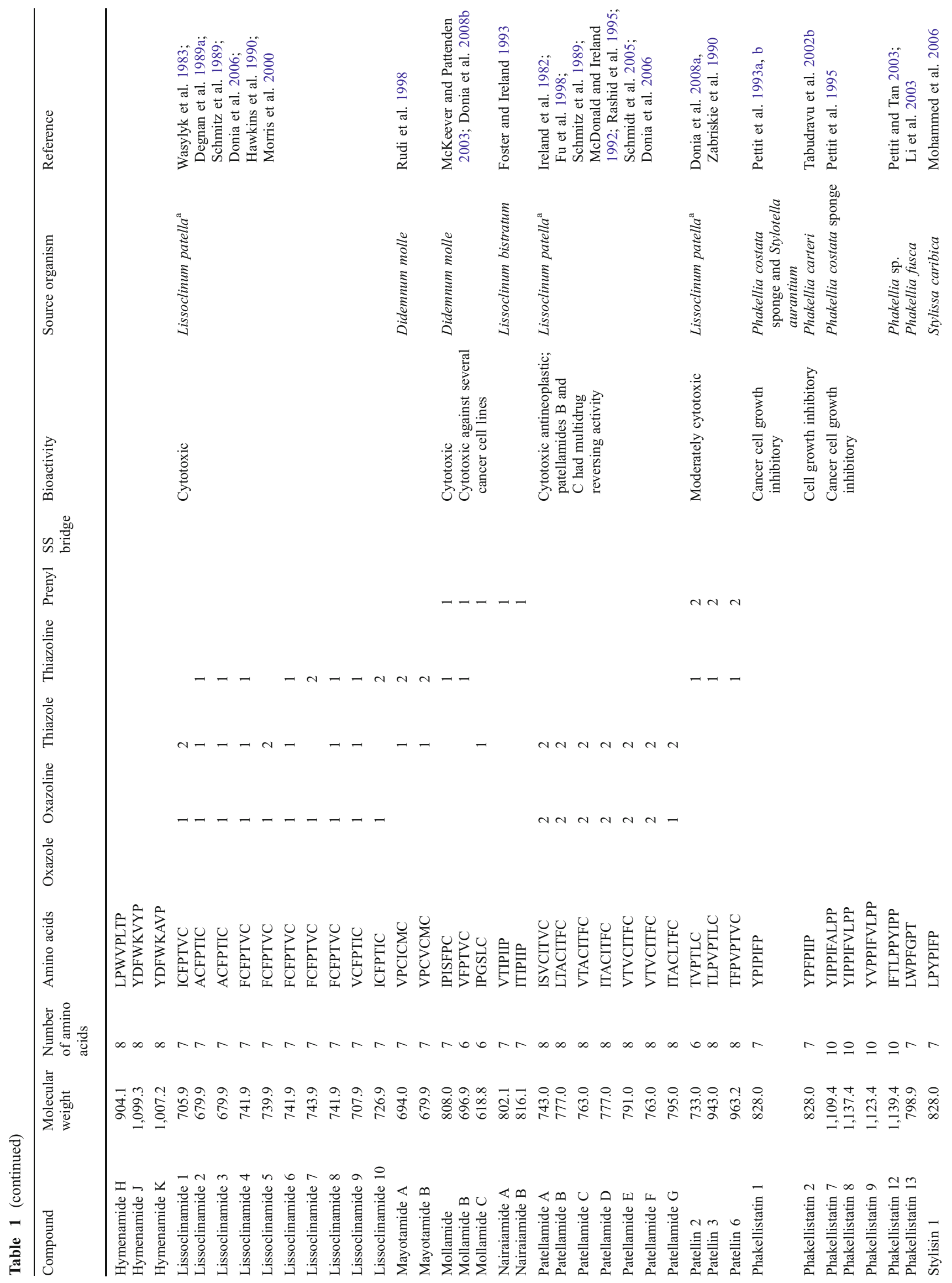


group of the N-terminal amino acid yielding a homodetic cyclic peptide. In cyanobactin biosynthesis, the precursor peptide directly encodes one or more cyanobactins flanked by the putative recognition sequences at which the precursor peptide is cleaved by two proteases (Schmidt et al. 2005; Lee et al. 2009). Cyanobactin precursor peptides encode more than one cyanobactin, and this could be a means to enhance the levels of peptide production or represent a mechanism for generating chemical diversity. The cyanobactin gene cluster encodes two proteases demonstrated to be involved in the cleavage of the precursor peptide and cyclization of the cyanobactin (Lee et al. 2009). The PatA protease encoded in the patellamide biosynthetic gene cluster was shown to cleave the precursor peptide at the $\mathrm{N}$-terminal recognition sequence while the PatG protease cleaved the precursor peptide at the C-terminal recognition sequence (Lee et al. 2009). However, only the PatG protease was required for $\mathrm{N}-\mathrm{C}$ cyclization of the cyanobactins (Lee et al. 2009).

The cyanobactin biosynthetic genes encoded in gene clusters are approximately $10 \mathrm{~kb}$ in size and contain between 7 and 12 genes (Fig. 2). The gene order is not strictly conserved (Fig. 2). However, most often, the biosynthetic genes are organized as in the patellamide pat gene cluster. All of the cyanobactin gene clusters contain two proteases, which work in tandem, a short precursor peptide as well as proteins involved in the maturation of the cyanobactins. The cyanobactin gene clusters in Prochloron are highly similar (Schmidt et al. 2005; Donia et al. 2006).

Thiazoles and oxazoles are formed through the heterocyclization and subsequent oxidation of cysteine, serine, and threonine amino acids. Cyanobactin gene clusters typically contain a gene encoding a PatD homolog which is predicted to heterocyclize cysteine, serine, and threonine to thiazolines and oxazolines (Schmidt et al. 2005). A PatF homolog is often encoded in cyanobactin gene clusters and thought to be involved in the heterocyclization and/or prenylation of cyanobactins (Schmidt and Donia 2009). The oxidase domain of the bimodular PatG protein is believed to catalyze the oxidation of thiazolines and oxazolines to thiazoles and oxazoles (Schmidt et al. 2005). Intriguingly, PatB and PatC are encoded in nearly all cyanobactin gene clusters but are nonessential, with patellamides being produced by heterologous expression of the pat gene cluster in Escherichia coli in the absence of the patB and patC genes (Donia et al. 2006, 2008a).

\section{Patellamides, lissoclinamides, ulithiacyclamides, and patellins}

Biologically active cyclic peptides have been reported from Lissoclinum patella ascidians, but the biosynthesis of the compounds is often attributed to the small photosynthetic 


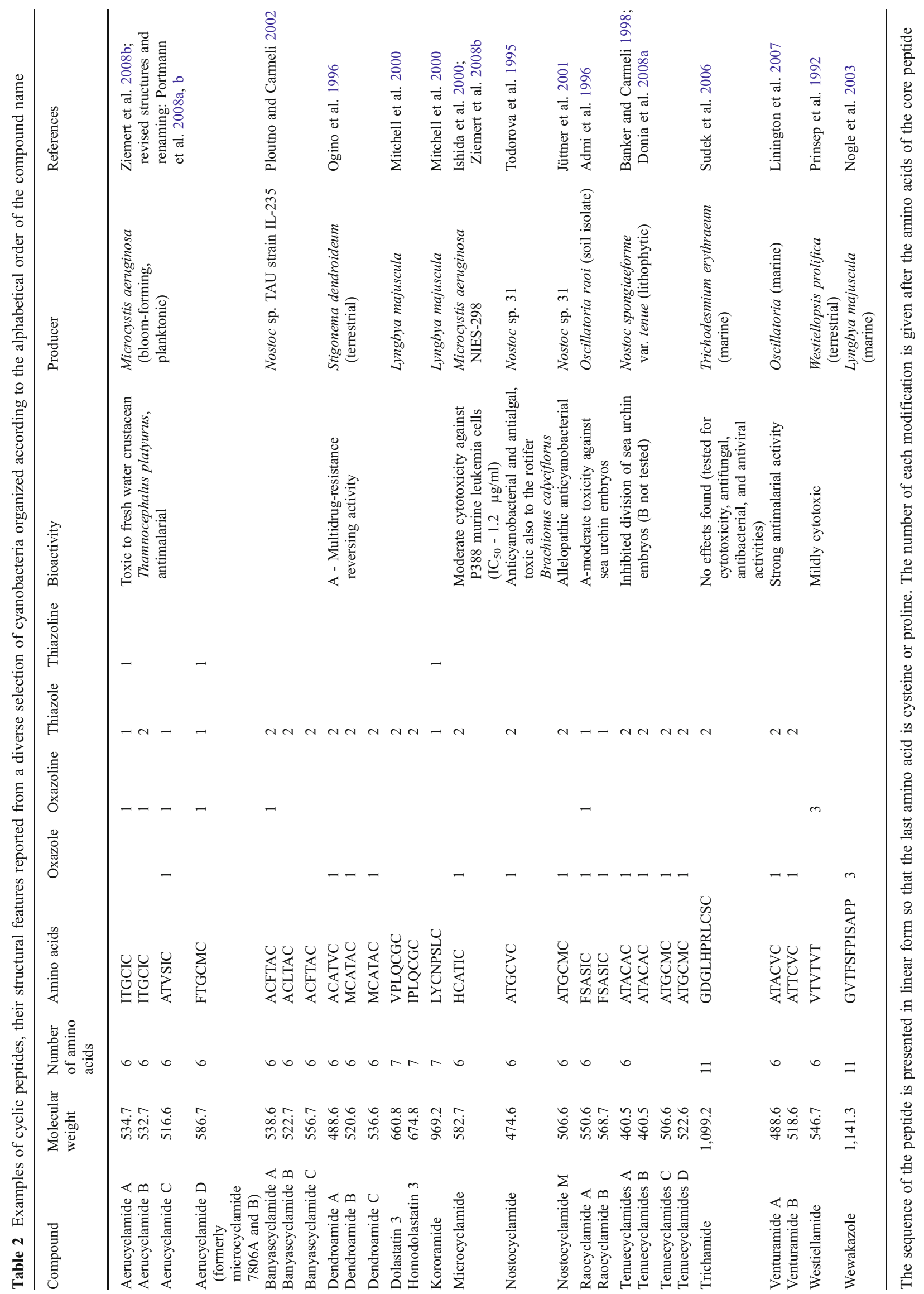




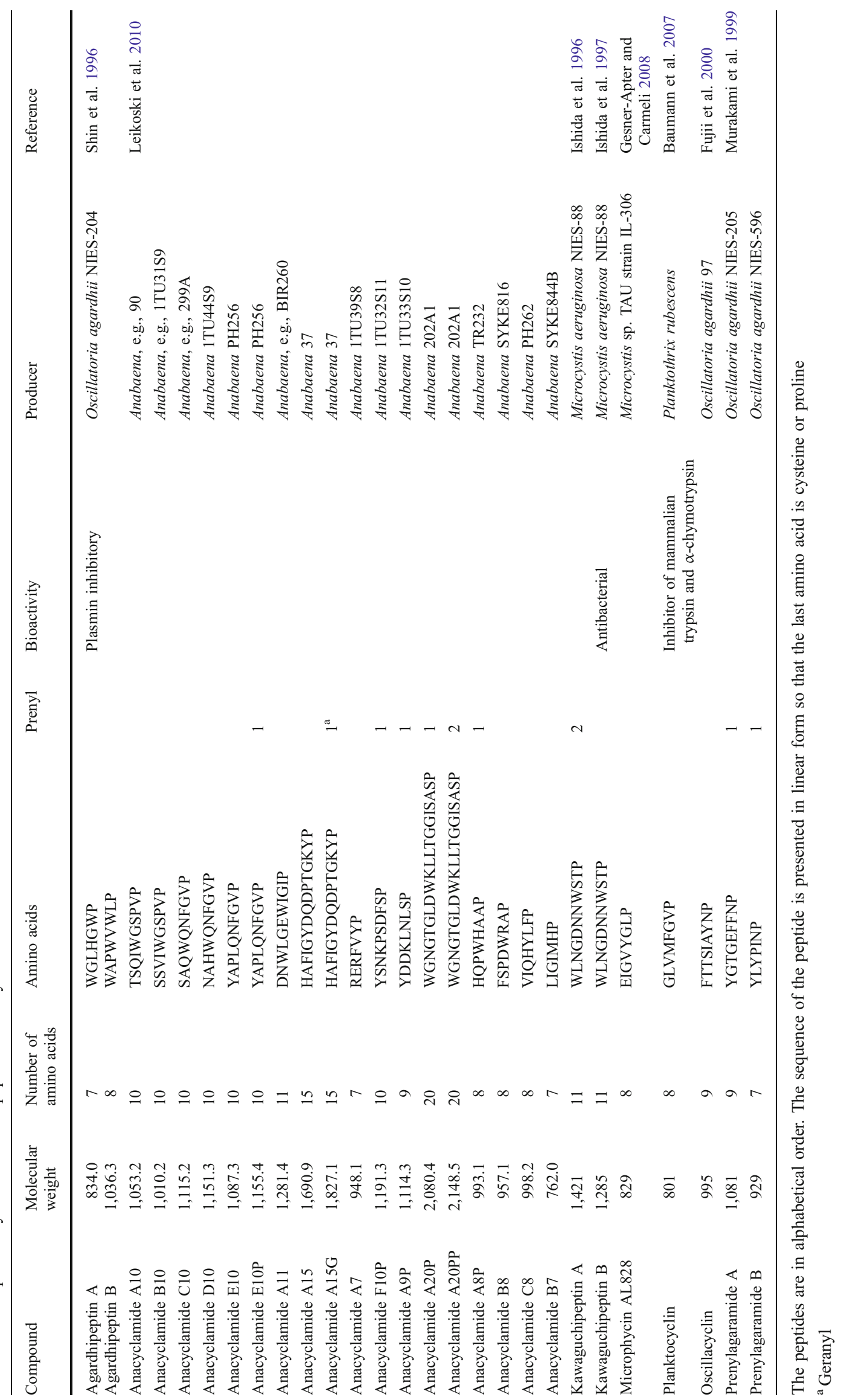


Fig. 2 Cyanobactin gene clusters published from seven distantly related cyanobacteria.

These gene clusters are typified by genes encoding proteases (yellow), a short precursor peptide $(\mathrm{red})$, proteins involved in the maturation of the cyanobactin (black), as well as conserved and hypothetical open reading frames (white)
Prochloron spp.

(patellamide)

Microcystis aeruginosa
(microcyclamide)

Nostoc spongiaeforme (tenuecyclamide)

Prochloron

(patellin, trunkamide)

Lyngbya aestuarii
(Lyngbyabactin)

Anabaena sp.

(anacyclamide)

Trichodesmium erythraeum (trichamide)

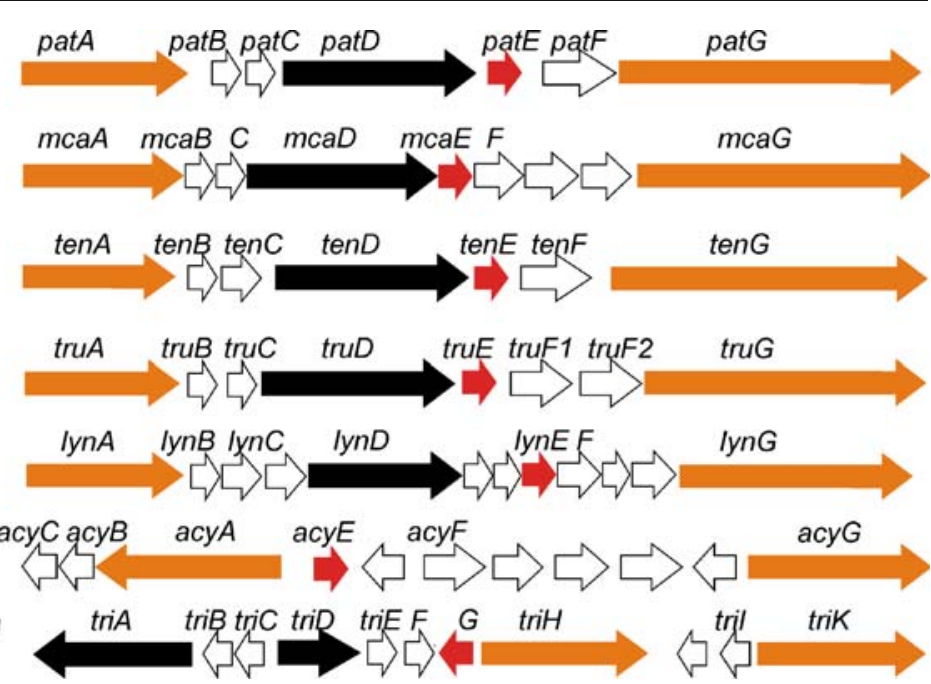

obligate symbionts of these ascidians (Sings and Rinehart 1996). The findings of Schmidt and coworkers demonstrated that the cyanobactin pathway was responsible for the production of patellamide in symbiotic uncultured Prochloron spp. as well as lissoclinamides, ulithiacyclamides, patellin, and the anticancer drug candidate trunkamide (Schmidt et al. 2005; Donia et al. 2006; Donia et al. 2008a). The cyanobactins which are produced by Prochloron spp. are structurally diverse and range in size from six to eight amino acids (Table 1, Schmidt et al. 2005; Donia et al. 2006, 2008a).

Ascidians harbor a mixture of symbiotic Prochloron strains. The portion of the precursor peptide gene encoding the core peptide in the cyanobactin gene clusters from Prochloron spp. is hypervariable. Hence, a library of cyanobactins is synthesized when multiple uncultivated Prochloron strains are present in the tunicate (Donia et al. 2006).

Patellins and trunkamides produced by uncultured symbiotic Prochloron spp. contain prenylated amino acids (Donia et al. 2008a). The prenylated cyanobactins do not have oxazoles or thiazoles, only unoxidized forms of these heterocyclized amino acids occur, and the oxidase domain of PatG is missing in the patellin and trunkamide biosynthetic gene cluster (Schmidt and Donia 2009). In addition, the prenylating pathway encodes two PatF proteins whose roles are unclear, and the prenylation is not fully understood at present (Schmidt and Donia 2009). Ulithiacyclamides contain four cysteines, two of which form a disulfide bridge and the other two cysteines are heterocyclized to thiazoles (Table 1). Among the more than hundred cyanobactins, disulfide bridges are only found in ulithiacyclamides (Tables 1, 2, and 3).

\section{Tenuecyclamides}

Tenuecyclamides are hexapeptides containing two thiazoles and an oxazole (Banker and Carmeli 1998, Table 2). A cyanobactin pathway for the biosynthesis of tenuecyclamide was characterized in an epilithic Nostoc spongiaeforme strain (Fig. 2, Donia et al. 2008a). The tenuecyclamide ten gene cluster has an identical gene organization to pat gene cluster as the genes are transcribed to the same direction, and the gene order is conserved. The TenE precursor peptide encodes four copies of the core peptide amino acid sequences which form tenuecyclamides A and C (Donia et al. 2008a). Tenuecyclamides A and B differ only in stereochemistry (Table 2).

\section{Trichamide}

Trichamide is cyclic 11 amino acid cyanobactin which contains two thiazoles (Sudek et al. 2006). This cyanobactin was discovered through genome mining of Trichodesmium erythraeum IMS101, a free-living, nitrogen-fixing filamentous marine cyanobacterium (Schmidt et al. 2005; Sudek et al. 2006). The tri gene cluster is $12.5 \mathrm{~kb}$ and encodes 11 open reading frames (ORFs) with a bidirectional gene order for which only six genes have an assigned function (Fig. 2, Sudek et al. 2006). The trichamide precursor peptide encodes a single copy of the trichamide core peptide flanked by the putative recognition sequences. In contrast to Pat proteins, the oxidase and the protease domains in Trichodesmium are encoded by separate genes (Sudek et al. 2006).

\section{Lyngbyabactins}

A cyanobactin gene cluster has been also identified from the genome of the marine Lyngbya aestuarii CCY9616 (Fig. 2, Donia et al. 2008a). The products of this gene cluster, lyngbyabactins A and B, were predicted from the precursor peptide LynE (Donia et al. 2008a). The peptides 
are predicted to include isoprenoid amino acid derivatives (Donia et al. 2008a). However, lyngbyabactins A and B have not yet been detected from L. aestuarii CCY9616. The lyngbyabactin biosynthetic gene cluster has homologs of all genes present in the pat gene cluster but it also contains five other open reading frames which have no function assigned (Donia et al. 2008a).

\section{Microcyclamides and aerucyclamides}

Microcyclamide is a cytotoxic cyclic hexapeptide reported from the freshwater bloom-forming cyanobacterium Microcystis aeruginosa NIES-298 (Ishida et al. 2000). The microcyclamides 7806A and B of $M$. aeruginosa PCC 7806 were later renamed as aerucyclamides, and the structures were revised (Portmann et al. 2008a, b). Microcyclamides and aerucyclamides are assembled via the cyanobactin biosynthetic pathway in two strains of M. aeruginosa NIES 298 and PCC 7806 (Ziemert et al. 2008b; Portmann et al. 2008a, b). The $m c a$ gene clusters have the same gene order as the pat genes except for two additional open reading frames for which no functions could be assigned (Fig. 2, Ziemert et al. 2008b). The McaE precursor peptide encodes two identical copies of the microcyclamide core peptides in M. aeruginosa NIES-298 (Ziemert et al. 2008b).

\section{Anacyclamides}

A variety of anacyclamides have been identified from strains of the genus Anabaena (Leikoski et al. 2010, Table 3). Anacyclamides consist of proteinogenic amino acids, and some contain prenyl or geranyl groups through the posttranslational modifications of specific amino acids. The acy gene cluster in Anabaena sp. 90 encodes 11 ORFs, and it is arranged in an eleven kb operon which is bidirectionally transcribed as the trichamide gene cluster (Fig. 2). The gene cluster differs from pat gene cluster in that there were no homologs for all pat genes. Additionally, there were hypothetical ORFs present in the acy gene cluster that were absent in the pat gene cluster (Leikoski et al. 2010). The precursor peptide AcyE encodes single copy of the anacyclamide A10 (Fig. 1) flanked by putative recognition sequences which differ substantially from other cyanobactin precursors (Leikoski et al. 2010). The anacyclamide gene cluster lacks a PatD homolog which agrees well with the anacyclamide structure which has no posttranslationally heterocyclized amino acids (Leikoski et al. 2010). The AcyG protein lacks an oxidase domain which is consistent with the absence of heterocyclized amino acids (Leikoski et al. 2010). In anacyclamides, the length of the peptides varies greatly which is achieved by expansion of the AcyE precursor protein. Anacyclamides showed great amino acid variation since only one proline was conserved (Table 3).

\section{Bioactivities}

The cyanobactins and cyclic peptides with analogous structures have various reported bioactivities (in detail, see Tables 1, 2 , and 3 ). The diverse bioactivities are derived from versatile structures, but all cyanobactins do not exhibit bioactivities in the tests used or those have not been studied yet (Tables 1, 2, and 3). Several of the cyanobacterial metabolites have been found to be anticancer compounds, e.g., trunkamide (Salvatella et al. 2003); some have multidrug reversing activities (Ogino et al. 1996) as well as activities against tropical parasites such as malaria-causing Plasmodium falciparum (Linington et al. 2007; Portmann et al. 2008b). In bacteria, many of the ribosomally produced peptides are antibiotics or bactericides produced to kill or inhibit growth of competing microbes (Nolan and Walsh 2009). Cyanobacteria are photosynthetic autotrophic organisms grazed by eukaryotic organisms. They are believed to form mutualistic association with heterotrophic bacteria, but this may not be always the case (Manage et al. 2000; Berg et al. 2009). Nostocyclamides for example have been shown to contain anticyanobacterial activity (Todorova et al. 1995; Jüttner et al. 2001). There are compounds isolated from cyanobacteria with antibiotic (Ishida et al. 1997) or antiviral (Boyd et al. 1997; Bokesch et al. 2003) effects, leaving open the option that some of the cyanobactins may prove to be antibiotic or antiviral compounds.

\section{Analogous pathways}

In addition to cyanobactins, another cyanobacterial peptide class, microviridins, was recently shown to be ribosomally produced in M. aeruginosa and Planktothrix agardhii, but their biosynthetic machinery differs from that of cyanobactins (Ziemert et al. 2008a; Philmus et al. 2008). These compounds were originally thought to be products of nonribosomal peptide biosynthesis. However, microviridins are synthesized from precursor peptides that are converted into tricyclic depsipeptides through the action of ATP grasp ligases and a transporter peptidase (Ziemert et al. 2008a; Philmus et al. 2008). The work of Philmus et al. (2008) reported similar gene clusters in the genomes of Anabaena variabilis, Nostoc punctiforme, and Nodularia spumigena as well as in genomes of other bacteria.

The biosynthetic gene clusters encoding the production pathway of ribosomal peptides with oxazoles and thiazoles are present in a broad range of bacteria (Lee et al. 2008). Bacteria distantly related to cyanobacteria are known to produce bacteriocins by the posttranslational modification 
of gene-encoded precursor peptides, including microcins and the lanthionine-containing lantibiotics of Gram-positive bacteria (Jack et al. 1995; Jack and Jung 2000; Nolan and Walsh 2009). Cyanobactin biosynthesis is analogous in many ways to the biosynthesis of bacteriocins (Franz et al. 2007; Nolan and Walsh 2009). The leader-peptide-guided biosynthesis is common in many ribosomally synthesized natural products where the precursor peptide is synthesized and cleaved, and in some cases the core peptide is posttranslationally modified (Oman and van der Donk 2010). Bacteriocins can be also circularized as cyanobactins, and some bacteriocins have similar posttranslational modifications as cyanobactins for example thiazoles and oxazoles (Jack and Jung 2000; Maqueda et al. 2008; Martin-Visscher et al. 2009).

Many of cyanobacterial bioactive compound classes are synthesized on nonribosomal peptide synthetases (NRPS) or combined NRPS and polyketide synthases (Welker and von Döhren 2006; Sivonen and Börner 2008). However, the cyanobactins have been shown to be produced by the posttranslational modification of the gene-encoded precursor peptides (e.g., Schmidt et al. 2005; Donia et al. 2008a). The gene clusters responsible for ribosomal peptide production are small compared to the large nonribosomal peptide synthetase gene clusters. In NRPS, variation in the chemical structure of the peptide is achieved by utilization of more than 200 nonproteinogenic amino acids (Nolan and Walsh 2009) whereas ribosomal peptides are restricted to 20 proteinogenic amino acids which may be posttranslationally modified. In NRPS, the enzymes seem to have relaxed substrate specificity and thus allow simultaneous production of a number of structural variants in the same strain of a cyanobacterium (Welker and von Döhren 2006).

\section{Biotechnological aspects}

The biotechnological exploitation of cyanobactins will require detailed studies on the enzymes involved in the biosynthesis as well as mechanisms of action of these peptides. It is possible to express the cyanobactin gene clusters in heterologous hosts (Schmidt et al. 2005; Donia et al. 2006, 2008a; Leikoski et al. 2010). The small size of the cyanobactin gene clusters and the expression of the entire clusters in heterologous hosts will provide new possibilities to create compound libraries and novel compounds (Donia et al. 2006, 2008a). In the cyanobactin pathway, heterologous expression gives options to study the role of individual genes in biosynthesis as well as produce novel peptides. The cyanobactin pathway was utilized in $E$. coli to synthesize an engineered peptide eptidemnamide, a cyclic peptide similar to an anticoagulant in clinical use
(Donia et al. 2006). This approach demonstrates a means to exploit cyanobacterial pathways and produce novel compounds by the rational design of peptides. The peptideprecursor-directed synthesis allows manipulations directly to the precursor gene and enables production of engineered peptides in heterologous hosts (Oman and van der Donk 2010). In addition, the enzymes in the cyanobactin pathways could be used as catalysts in aiding chemical synthesis of the desired compounds. The work by Lee et al. (2009) not only clarified the role of proteases in the cyanobactin biosynthesis but demonstrated the potential of the enzyme as general catalysts for cyclization of peptides. The technological advantages of the PatG protease were that no energy is required for the cleavage and cyclization, and also the protease was proven to be tolerant of different substrate lengths and sequences as long as the $\mathrm{C}$-terminal recognition sequence was present (Lee et al. 2009). This is important as in synthetic peptide manufacture the head-to-tail cyclization step restricts peptide production in bulk amounts.

It should be noted that whole-genome information has already led to the discovery of cyanobactin biosynthesis as well as several new compounds and compound classes, e.g., patellamides (Schmidt et al. 2005), trichamide (Sudek et al. 2006), and anacyclamides (Leikoski et al. 2010). The increasing number of genome projects on cyanobacteria and metagenomic studies (Schmidt and Donia 2009) applied to various environments are likely to yield new discoveries including diverse ribosomal pathways and novel cyanobactins in the future.

Acknowledgements This work was supported by grants from the Academy of Finland to K.S. (Research Center of Excellence grant 118637 and Academy Professors grant 214457). N.L. is a student at the Viikki Graduate School in Molecular Biosciences.

Open Access This article is distributed under the terms of the Creative Commons Attribution Noncommercial License which permits any noncommercial use, distribution, and reproduction in any medium, provided the original author(s) and source are credited.

\section{References}

Admi V, Afek U, Carmeli S (1996) Raocyclamides A and B, novel cyclic hexapeptides isolated from the cyanobacterium Oscillatoria raoi. J Nat Prod 59:396-399

Arrault A, Witczak-Legrand A, Gonzalez P, Bontemps-Subielos N, Banaigs B (2002) Structure and total synthesis of cyclodidemnamide B, a cycloheptapeptide from the ascidian Didemnum molle. Tetrahedron Lett 43:4041-4044

Banker R, Carmeli S (1998) Tenuecyclamides A-D, cyclic hexapeptides from the cyanobacterium Nostoc spongiaeforme var. tenue. J Nat Prod 61:1248-1251

Baumann HI, Keller S, Wolter FE, Nicholson GJ, Jung G, Susmuth RD, Jüttner F (2007) Planktocyclin, a cyclooctapeptide protease inhibitor produced by the freshwater cyanobacterium Planktothrix rubescens. J Nat Prod 70:1611-1615 
Berg KA, Lyra C, Sivonen K, Paulin L, Suomalainen S, Tuomi P, Rapala J (2009) High diversity of cultivable heterotrophic bacteria in association with cyanobacterial water blooms. ISME Journal 3:314-325

Bokesch HR, O'Keefe BR, McKee TC, Pannell LK, Patterson GML, Gardellina RS II, Sowder RC, Turpin J, Watson K, Buckheit RW Jr, Boyd MR (2003) A potent novel anti-HIV protein from the cultured cyanobacterium Scytonema varium. Biochemistry 42:2578-2584

Boyd MR, Gustafson KR, McMahon JB, Shoemaker RH, O'Keefe BR, Mori T, Gulakowski RJ, Wu L, Rivera MI, Laurencot CM, Currens MJ, Cardellina JH 2nd, Buckheit RW Jr, Nara PL, Pannell LK, Sowder RC 2nd, Henderson LE (1997) Discovery of cyanovirin-N, a novel human immunodeficiency virus-inactivating protein that binds viral surface envelope glycoprotein gp 120: potential applications to microbicide development. Antimicrob Agents Chemother 42:1521-1530

Burja AM, Bagnais B, Abou-Mansour E, Burgess JG, Wright PC (2001) Marine cyanobacteria - a prolific source of natural products. Tetrahedron 57:9347-9377

Caba JM, Rodriguez IM, Manzanares I, Giralt E, Albericio F (2001) Solidphase total synthesis of trunkamide A1. J Org Chem 66:7568-7574

Degnan BM, Hawkins CJ, Lavin MF, McCaffrey EJ, Parry DL, van den Brenk AL, Watters DJ (1989a) New cyclic peptides with cytotoxic activity from the ascidian Lissoclinum patella. J Med Chem 32:1349-1354

Degnan BM, Hawkins CJ, Lavin MF, McCaffrey EJ, Parry DL, Watters DJ (1989b) Novel cytotoxic compounds from the ascidian Lissoclinum bistratum. J Med Chem 32:1354-1359

Donia MS, Hathaway BJ, Sudek S, Haygood MG, Rosovitz MJ, Ravel J, Schmidt EW (2006) Natural combinatorial peptide libraries in cyanobacterial symbionts of marine ascidians. Nat Chem Biol 2:729-735

Donia MS, Ravel J, Schmidt EW (2008a) A global assembly line for cyanobactins. Nat Chem Biol 4:341-343

Donia MS, Wang B, Dunbar DC, Desai PV, Pathy A, Avery M, Hamann MT (2008b) Mollamides B and C, cyclic hexapeptides from the Indonesian tunicate Didemnum molle. J Nat Prod 71:941-945

Foster MP, Ireland CM (1993) Nairaiamide A and nairaiamide B-2 novel di-proline heptapeptides isolated from a Fijian Lissoclinum-Bistratum ascidian. Tetrahedron Lett 34:2871-2874

Foster MP, Concepción GP, Caraan GB, Ireland CM (1992) Bistratamides C and D. Two new oxazole-containing cyclic hexapeptides isolated from a Philippine Lissoclinum bistratum ascidian. J Org Chem 57:6671-6675

Franz CMAP, van Belkum MJ, Holzapfel WH, Abriouel H, Galvez A (2007) Diversity of enterococcal bacteriocins and their grouping in a new classification scheme. FEMS Microbiol Rev 31:293-310

Fu X, Do T, Schmitz FJ, Andrusevich V, Engel MH (1998) New cyclic peptides from the ascidian Lissoclinum patella. J Nat Prod 61:1547-1551

Fujii K, Sivonen K, Naganawa E, Harada KI (2000) Non-toxic peptides from toxic cyanobacteria, Oscillatoria agardhii. Tetrahedron 56:725-733

Gesner-Apter S, Carmeli S (2008) Three novel metabolites from a bloom of the cyanobacterium Microcystis sp. Tetrahedron 64:6628-6634

Guan LL, Sera Y, Adachi K, Nishida F, Shizuri Y (2001) Isolation and evaluation of nonsiderophore cyclic peptides from marine sponges. Biochem Biophys Res Commun 283:976-981

Hambley TW, Hawkins CJ, Lavin MF, van den Brenk A, Watters DJ (1992) Cycloxazoline: a cytotoxic cyclic hexapeptide from the ascidian Lissoclinum bistratum. Tetrahedron 48:341-348

Hawkins CJ, Lavin MF, Marshall KA, van den Brenk AL, Watters DJ (1990) Structure-activity relationships of the lissoclinamides: cytotoxic cyclic peptides from the ascidian Lissoclinum patella. J Med Chem 33:1634-1638
Ireland CM, Scheuer PJ (1980) Ulicyclamide and ulithiacyclamide, two new small peptides from a marine tunicate. J Am Chem Soc 102:5688-5691

Ireland CM, Durso AR Jr, Newman RA, Hacker MP (1982) Antineoplastic cyclic peptides from the marine tunicate Lissoclinum patella. J Org Chem 47:1807-1811

Ishida T, Tanaka M, Nabae M, Inoue M (1988) Solution and solidstate conformations of ascidiacyclamide, a cytotoxic cyclic peptide from ascidian. J Org Chem 53:107-112

Ishida K, Matsuda H, Murakami M, Yamaguchi K (1996) Kawaguchipeptin A, a novel cyclic undecapeptide from cyanobacterium Microcystis aeruginosa (NIES-88). Tetrahedron 52:9025-9030

Ishida K, Matsuda H, Murakami M, Yamaguchi K (1997) Kawaguchipeptin $\mathrm{B}$, an antibacterial cyclic undecapeptide from the cyanobacterium Microcystis aeruginosa. J Nat Prod 60:724-726

Ishida K, Nakagawa H, Murakami M (2000) Microcyclamide, a cytotoxic cyclic hexapeptide from the cyanobacterium Microcystis aeruginosa. J Nat Prod 63:1315-1317

Jack RW, Jung G (2000) Lantibiotics and microcins: polypeptides with unusual chemical diversity. Curr Opin Chem Biol 4:310-317

Jack RW, Tagg JR, Ray B (1995) Bacteriocins of Gram-positive bacteria. Microbiol Rev 59:171-200

Jüttner F, Todorova AK, Walch N, von Philipsborn W (2001) Nostocyclamide M: a cyanobacterial cyclic peptide with allelopathic activity from Nostoc 31. Phytochemistry 57:613-619

Kobayashi J, Tsuda M, Nakamura T, Mikami Y, Shigemori H (1993) Hymenamide A and hymenamide B, new proline-rich cyclic heptapeptides from the Okinawan marine sponge Hymeniacidon sp. Tetrahedron 49:2391-2402

Lee SW, Mitchell DA, Markley AL, Hensler ME, Gonzalez D, Wohlrab A, Dorrestein PC, Nizet V, Dixon JE (2008) Discovery of a widely distributed toxin biosynthetic gene cluster. Proc Natl Acad Sci U S A 105:5879-5884

Lee J, McIntosh J, Hathaway BJ, Schmidt EW (2009) Using marine natural products to discover a protease that catalyses peptide macrocyclization of diverse substrates. J Am Chem Soc 131:2122-2124

Leikoski N, Fewer DP, Sivonen K (2009) Widespread occurrence and lateral transfer of the cyanobactin biosynthesis gene cluster in cyanobacteria. Appl Environ Microbiol 75:853-857

Leikoski N, Fewer DP, Jokela J, Wahlsten M, Rouhiainen L, Sivonen K (2010) Highly diverse cyanobactins in strains of the genus Anabaena. Appl Environ Microbiol 76:701-709

Li WL, Yi YH, Wu HM, Xu QZ, Tang HF, Zhou DZ, Lin HW, Wang ZH (2003) Isolation and structure of the cytotoxic cycloheptapeptide phakellistatin 13. J Nat Prod 66:146-148

Linington RG, Gonzàles J, Ureña L-D, Romero LI, Ortega-Barria E, Gerwick WH (2007) Venturamides A and B: antimalarial constituents of the Panamanian marine cyanobacterium Oscillatoria sp. J Nat Prod 70:397-401

Manage PM, Kawabata Z, Nakano S-I (2000) Algicidal effect of the bacterium Alcaligenes denitrificans on Microcystis spp. Aquat Microb Ecol 22:111-117

Maqueda M, Sanchez-Hidalgo M, Fernandez M, Montalban-Lopez M, Valdivia E, Martinez-Bueno M (2008) Genetic features of circular bacteriocins produced by Gram-positive bacteria. FEMS Microbiol Rev 32:2-22

Martin-Visscher LA, Gong XD, Duszyk M, Vederas JC (2009) The three-dimensional structure of carnocyclin A reveals that many circular bacteriocins share a common structural motif. J Biol Chem 284:28674-28681

McDonald LA, Ireland CM (1992) Patellamide E: a new cyclic peptide from the ascidian Lissoclinum patella. J Nat Prod 55:376-379

McDonald LA, Foster MP, Phillips DR, Ireland CM, Lee AY, Clardy J (1992) Tawicyclamides A and B, new cyclic peptides from the ascidian Lissoclinum patella: studies on the solution- and solidstate conformations. J Org Chem 57:4616-4624 
McKeever B, Pattenden G (2003) Total synthesis of the cytotoxic cyclopeptide mollamide, isolated from the sea squirt Didemnum molle. Tetrahedron 59:2701-2712

Milanowski DJ, Rashid MA, Gustafson KR, O'Keefe BR, Nawrocki JP, Pannell LK, Boyd MR (2004) Cyclonellin, a new cyclic octapeptide from the marine sponge Axinella carteri. J Nat Prod 67:441-444

Mitchell SS, Faulkner DJ, Rubins K, Bushman FD (2000) Dolastatin 3 and two novel cyclic peptides from a Palauan collection of Lyngbya majuscula. J Nat Prod 63:279-282

Mohammed R, Peng J, Kelly M, Hamann MT (2006) Cyclic heptapeptides from the Jamaican sponge Stylissa caribica. J Nat Prod 69:1739-1744

Morris LA, van den Bosch JJK, Versluis K, Thompson GS, Jaspars M (2000) Structure determination and MSn analysis of two new lissoclinamides isolated from the Indo-Pacific ascidian Lissoclinum patella: NOE restrained molecular dynamics confirms the absolute stereochemistry derived by degradative methods. Tetrahedron 56:8345-8353

Murakami M, Itou Y, Ishida K, Shin HJ (1999) Prenylagaramides A and $\mathrm{B}$, new cyclic peptides from two strains of Oscillatoria agardhii. J Nat Prod 62:752-755

Napolitano A, Bruno I, Rovero P, Lucas R, Peris MP, Gomez-Paloma L, Riccio R (2001) Synthesis, structural aspects and bioactivity of the marine cyclopeptide hymenamide C. Tetrahedron 57:6249-6255

Nogle LM, Marquez BL, Gerwick WH (2003) Wewakazole, a novel cyclic dodecapeptide from a Papua New Guinea Lyngbya majuscula. Org Lett 5:3-6

Nolan EM, Walsh CT (2009) How nature morphs peptide scaffolds into antibiotics. ChemBioChem 10:34-53

Ogino J, Moore RE, Patterson GML, Smith CD (1996) Dendroamides, new cyclic hexapeptides from blue-green alga. Multidrug-resistance reversing activity of dendroamide A. J Nat Prod 59:581-586

Ojika M, Nemoto T, Nakamura M, Yamada K (1995) Dolastatin E, a new cyclic hexapeptide isolated from the sea hare Dolabellaauricularia. Tetrahedron Lett 36:5057-5058

Oman TJ, van der Donk WA (2010) Follow the leader: the use of leader peptides to guide natural product biosynthesis. Nat Chem Biol 6:9-18

Perez LJ, Faulkner DJ (2003) Bistratamides E-J, modified cyclic hexapeptides from the Philippines ascidian Lissoclinum bistratum. J Nat Prod 66:247-250

Pettit GR, Tan R (2003) Antineoplastic agents 390. Isolation and structure of phakellistatin 12 from a Chuuk archipelago marine sponge. Bioorg Med Chem Lett 13:685-688

Pettit GR, Cichacz Z, Barkoczy J, Dorsaz AC, Herald DL, Williams MD, Doubek DL, Schmidt JM, Tackett LP, Brune DC, Cerny RL, Hooper JNA, Bakus GJ (1993a) Antineoplastic agents. 249. Isolation and structure of the marine sponge cell-growth inhibitory cyclic peptide phakellistatin 1 . J Nat Prod 56:260-267

Pettit GR, Tan R, Williams MD, Tackett L, Schmidt JM, Cerny RL, Hooper JNA (1993b) Isolation and structure of phakellistatin 2 from the eastern Indian-ocean marine Sponge Phakellia carteri. Bioorg Med Chem Lett 3:2869-2874

Pettit GR, Gao F, Cerny RL, Doubek DL, Tackett LP, Schmidt JM, Chapuis JC (1994) Antineoplastic agents. 278. Isolation and structure of axinastatin 2 and axinastatin 3 from a western Caroline island marine sponge. J Med Chem 37:1165-1168

Pettit GR, Xu JP, Dorsaz AC, Williams MD, Boyd MR, Cerny RL (1995) Antineoplastic agents series contribution. 324. Isolation and structure of the human cancer cell-growth inhibitory cyclic decapeptides phakellistatin 7, phakellistatin 8 and phakellistatin 9. Bioorg Med Chem Lett 5:1339-1344

Philmus B, Christiansen G, Yoshida WY, Hemscheidt TK (2008) Posttranslational modification in microviridin biosynthesis. ChemBioChem 9:3066-3073

Ploutno A, Carmeli S (2002) Modified peptides from a water bloom of the cyanobacterium Nostoc sp. Tetrahedron 58:9949-9957
Portmann C, Blom JF, Gademann K, Jüttner F (2008a) Aerucyclamides $\mathrm{A}$ and $\mathrm{B}$ : isolation and synthesis of toxic ribosomal heterocyclic peptides from the cyanobacterium Microcystis aeruginosa PCC 7806. J Nat Prod 71:1193-1196

Portmann C, Blom JF, Kaiser M, Brun R, Jüttner F, Gademann K (2008b) Isolation of aerucyclamides C and D and structure revision of microcyclamide 7806A: heterocyclic ribosomal peptides from Microcystis aeruginosa PCC 7806 and their antiparasite evaluation. J Nat Prod 71:1891-1896

Prinsep MR, Moore RE, Levine IA, Patterson GML (1992) Westiellamide, a bistratamide-related cyclic peptide from the blue-green alga Westiellopsis prolifica. J Nat Prod 55:140-142

Rashid MA, Gustafson KR, Cardellina JH II, Boyd MR (1995) Patellamide F, a new cytotoxic cyclic peptide from the colonial ascidian Lissoclinum patella. J Nat Prod 58:594-597

Rouhiainen L, Paulin L, Suomalainen S, Hyytiäinen H, Buikema W, Haselkorn H, Sivonen K (2000) Genes encoding synthetases of cyclic depsipeptides, anabaenopeptilides, in Anabaena strain 90. Molecular Microbiol 37:156-167

Rudi A, Aknin M, Gaydou EM, Kashman Y (1998) Four new cytotoxic cyclic hexa- and heptapeptides from the marine ascidian Didemnum molle. Tetrahedron 54:13203-13210

Rudi A, Chill L, Aknin M, Kashman Y (2003) Didmolamide A and B, two new cyclic hexapeptides from the marine ascidian Didemnum molle. J Nat Prod 66:575-577

Salvatella X, Caba JM, Albericio F, Giralt E (2003) Solution structure of the antitumor candidate trunkamide $\mathrm{A}$ by $2 \mathrm{D}$ NMR and restrained simulated annealing methods. J Org Chem 68:211-215

Schmidt EW, Donia MS (2009) Cyanobactin ribosomally synthesized peptides - a case of deep metagenome mining. Meth Enzymol 458:575-596

Schmidt EW, Nelson JT, Rasko DA, Sudek S, Eisen JA, Haygood MG, Ravel J (2005) Patellamide A and C biosynthesis by a microcin-like pathway in Prochloron didemni, the cyanobacterial symbiont of Lissoclinum patella. Proc Natl Acad Sci U S A 102:7315-7320

Schmidt G, Grube A, Kock M (2007) Stylissamides A-D-new proline-containing cyclic heptapeptides from the marine sponge Stylissa caribica. European J Org Chem 24:4103-4110

Schmitz FJ, Ksebati MB, Chang JS, Wang JL, Hossain MB, van der Helm D (1989) Cyclic peptides from the ascidian Lissoclinum patella: conformational analysis of patellamide D by X-ray analysis and molecular modelling. J Org Chem 54:3463-3472

Sera Y, Adachi K, Fujii K, Shizuri Y (2003) A new antifouling hexapeptide from a Palauan sponge, Haliclona sp. J Nat Prod 66:719-721

Shin HJ, Matsuda H, Murakami M, Yamaguchi K (1996) Agardhipeptins $\mathrm{A}$ and $\mathrm{B}$, two new cyclic hepta- and octapeptide, from the cyanobacterium Oscillatoria agardhii (NIES-204). Tetrahedron 52:13129-13136

Sings HL, Rinehart KL (1996) Compounds produced from potential tunicate-blue-green algal symbiosis: a review. J Ind Microbiol Biotechnol 17:385-396

Sivonen K, Börner T (2008) Bioactive compounds produced by cyanobacteria. In: Herraro A, Flores E (eds) The cyanobacteria: molecular biology, genomics and evolution. Caister Academic, Norfolk, pp 159-197

Sone H, Kigoshi H, Yamada K (1997) Isolation and stereostructure of dolastatin I, a cytotoxic cyclic hexapeptide from the Japanese sea hare Dolabella auricularia. Tetrahedron 53:8149-8154

Sudek S, Haygood MG, Youssef DTA, Schmidt EW (2006) Structure of trichamide, a cyclic peptide from the bloom-forming cyanobacterium Trichodesmium erythraeum, predicted from the genome sequence. Appl Environ Microbiol 72:4382-4387

Tabudravu J, Morris LA, Kettenes-van den Bosch JJ, Jaspars M (2001) Wainunuamide, a histidine-containing proline-rich cyclic 
heptapeptide isolated from the Fijian marine sponge Stylotella aurantium. Tetrahedron Lett 42:9273-9276

Tabudravu JN, Morris LA, Kettenes-van den Bosch JJ, Jaspars M (2002a) Axinellin C, a proline-rich cyclic octapeptide isolated from the Fijian marine sponge Stylotella aurantium. Tetrahedron 58:7863-7868

Tabudravu JN, Jaspars M, Morris LA, Kettenes-van den Bosch JJ, Smith N (2002b) Two distinct conformers of the cyclic heptapeptide phakellistatin 2 isolated from the Fijian marine sponge Stylotella aurantium. J Org Chem 67:8593-8601

Teruya T, Sasaki H, Suenaga K (2008) Hexamollamide, a hexapeptide from an Okinawan ascidian Didemnum molle. Tetrahedron Lett 49:5297-5299

Tillett D, Dittmann E, Erhard M, von Döhren H, Börner T, Neilan BA (2000) Structural organization of microcystin biosynthesis in Microcystin aeruginosa PCC7806: an integrated peptidepolyketide synthetase system. Chem Biol 7:753-764

Todorova AK, Jüttner F, Linden A, Plüss T, von Philipsborn W (1995) Nostocyclamide: a new macrocyclic, thiazole-containing allelochemical from Nostoc sp. 31 (cyanobacteria). J Org Chem 60:7891-7895

Toske SG, Fenical W (1995) Cyclodidemnamide - a new cyclic heptapeptide from the marine ascidian Didemnum molle. Tetrahedron Lett 36:8355-8358
Tsuda M, Sasaki T, Kobayashi J (1994) Hymenamide G, hymenamide $\mathrm{H}$, hymenamide $\mathrm{J}$, and hymenamide- $\mathrm{K}$, 4 new cyclic octapeptides from the Okinawan marine sponge Hymeniacidon sp. Tetrahedron 50:4667-4680

Wasylyk JM, Biskupiak JE, Costello CE, Ireland CM (1983) Cyclic peptide structures from the tunicate Lissoclinum patella by FAB mass spectrometry. J Org Chem 48:4445-4449

Welker M, von Döhren H (2006) Cyanobacterial peptides-nature's own combinatorial biosynthesis. FEMS Microbiol Rev 30:530 563

Williams DE, Moore RE, Paul VJ (1989) The structure of ulithiacyclamide B. Antitumor evaluation of cyclic peptides and macrolides from Lissoclinum patella. J Nat Prod 52:732-739

Zabriskie TM, Foster MP, Stout TJ, Clardy J, Ireland CM (1990) Studies on the solution- and solid-state structure of patellin 2. J Am Chem Soc 112:8080-8084

Ziemert N, Ishida K, Liaimer A, Hertweck C, Dittmann E (2008a) Ribosomal synthesis of tricyclic depsipeptides in bloom-forming cyanobacteria. Angew Chem Int Ed 47:7756-7759

Ziemert N, Ishida K, Quillardet P, Bouchier C, Hertweck C, Tandeau de Marsac N, Dittmann E (2008b) Microcyclamide biosynthesis in two strains of Microcystis aeruginosa: from structure to genes and vice versa. Appl Environ Microbiol 74:1791-1797 